\title{
A VERTIKÁLISAN INTEGRÁLT VÁLLALATOK STRATÉGIAI LEHETŐSÉGEI AZ EURÓPAI UNIÓ LIBERALIZÁLT VILLAMOSENERGIA-PIACAIN
}

Az Európai Unió villamosenergia-piacait éró szabályozási változások és szerkezeti átalakulások új szereplói csoportokat hívtak életre, és megbolygatták a korábbi ágazati erôviszonyokat. Míg a monopol piaci körülmények között a vertikálisan integrált vállalatok stratégiai döntései elsôsorban a hosszú távú beruházási döntésekre korlátozódtak, ma már kiemelt figyelmet kell szentelniük a fogyasztók elvárásaira, versenytársaik lépéseire. A szerzó tanulmányában azt vizsgálja meg, milyen vállalati és üzleti stratégiákat követnek, követhetnek a domináns piaci részesedéssel bíró vállalatok.

\section{Kulcsszavak: liberalizáció, villamosenergia-ágazat, stratégiai csoportok}

A villamosenergia-rendszer kialakulása és fejlődése során a villamosenergia-ellátás szereplói vertikálisan integrált szolgáltatókká váltak, ôk állították elő, szállították, osztották el és értékesítették monopol piaci körülmények között a villamos energiát. Az elmúlt évtizedekben a villamosenergia-ágazat az Európai Unió tagállamaiban jelentôs változásokon ment keresztül. Az egyes országokban, többé-kevésbé eltérô módon lezajlott privatizáció, liberalizáció és dereguláció megnyitotta a korábbi monopol piacokat a verseny számára, helyesebben szólva, a teljes elláási láncot a verseny számára nyitott (termelés, kereskedelem, szolgáltatás) és továbbra is szabályozott (szállítás és elosztás) tevékenységekre tagolta. Bár a piacnyitás, a szektorspecifikus strukturális változások, a környezetvédelmi szabályozás szigorodása, a megújuló energiahordozókra épülő technológiák ösztönzése stb. révén új vállalati és stratégiai csoportok is megjelentek, az ágazat vizsgálatával foglalkozó kutatások (pl. Finon - Midttun, 2004; Sioshansi, 2008) azt sugallják, hogy a kimagasló pénzügyi és múködési teljesítménnyel továbbra is a részben vagy egészben vertikálisan integrált vállalatok, vállalatcsoportok bírnak. Ugyanakkor a makrokörnyezeti és ágazati változások hatására e vállalatok is szerepeik és stratégiáik újragondolására kényszerülnek. Jelen cikk célja tehát, hogy megvizsgálja, milyen változásokat idézett elő a szektor liberalizációja a vertikálisan integrált szereplő́k vállalati és üzletági stratégiáiban. A domináns szereplők vállalati és üzleti stratégiáival kapcsolatos megállapításokat pedig a stratégiai csoportok elemzésének módszerével kívánom igazolni.

\section{A piaci liberalizáció hatása a villamosenergia- ellátási láncra az Európai Unióban}

Az 1990-es évekig a villamosenergia-ágazat múködésének feltételeit világszerte az erős állami befolyásolás és a vertikálisan integrált szervezeti struktúra jellemezte, melynek fő indokai az alábbiakban keresendók (Chao et al., 2008: p. 30.):

- A villamos energia olyan - más javakkal nem, vagy csak korlátozottan helyettesíthetố - közjószág, mely alapvetố szükségleteket elégít ki, hozzájárul egy adott terület, ország gazdasági fejlődéséhez. Így a folyamatos, biztonságos és hatékony szolgáltatás állami szerepvállalást indokol.

- A szállítást és elosztást biztosító infrastruktúrát természetes monopóliumoknak kell tekinteni, duplikációjukat célszerú kerülni, kivéve, ha az javítja a hálózat biztonságát, a szolgáltatás megbízhatóságát. 
- Méretgazdaságosság: a természetes monopóliumok a termelésre is kiterjednek, és támogatják a nagyméretú és a nagy tôkeszükségletú erómúvek létrehozását.

- Választékgazdaságosság: az egyes tevékenységek közötti szoros kontroll biztosította előnyök a helyettesítési elónyökre, illetve a tudás, a képességek, a technológia és az információs rendszerek megosztásának lehetôségére vonatkoznak.

- Tranzakciós költségek gazdaságossága: A szolgáltatók beruházásai hosszú távon térülnek meg, visszafordíthatatlanok, az eszközök más célokra nem alkalmazhatók. A beruházások értékét így a várható fogyasztói értékesítés mennyisége adja. Mivel az egyes ellátásilánc-szintek közötti szerzôdések nem tudnak minden nem várt körülményre kiterjedni, számos kockázatot hordoznak magukban, támogatva a vertikális integrációt. A beruházások eszközspecifikussága és magas tốkeszükséglete miatt az állam feladata a beruházások kockázatának csökkentése és az országos méretú hatékony vezetékrendszerek létrehozása.

- A villamos energia nagy mennyiségben történố tárolása nem megoldott, a kínálat és kereslet folyamatos egyensúlyban tartása csak bizonyos mértékú állami ellenơrzés mellett lehetséges.

Az elmúlt évtizedekben azonban a világ szinte minden országában tanúi lehettünk a villamosenergiaszektort érintô, a piac újrastrukturálását, az intézményi és szabályozási reformokat, az üzleti stratégiák reorientációját, a fogyasztók újrafelfedezését, a különbözô szintú technológiai fejlesztéseket ösztönző liberalizációs, de-, illetve reregulációs és dezintegrációs folyamatoknak. Annak ellenére, hogy ezek a folyamatok az egyes országokban más-más formát öltöttek, az alapjukat képező gazdasági elgondolás ugyanaz: a vertikálisan integrált vállalatok természetes monopóliumként való kezelése helyett ma már a termelési és elosztási versenytől várják, hogy megteremtse a választás lehetôségét, tegye lehetôvé a különbözô ellátási struktúrák megjelenését, valamint a társadalom egészét, a vállalatok versenyképességét befolyásoló árak mérséklődését. Mindezt tovább támogatja a termelési technológiák területén tapasztalható fejlődés. A kisteljesítményú és kapcsolt termelési egységek megjelenése révén a hagyományos „méretgazdaságosságra” épülő szemléletet felváltja a „,moduláris sorozatgazdaságosság" elve. Eszerint a decentralizált villamosenergia-rendszereknél a tanulási hatás és a tömegtermelés kompenzálhatja a meglévő villamosenergia-rendszer méretgazdaságossági hatásait. Jelentősen visszaesett a hálózatok eszközspecifikusságának mértéke is, miközben az informatika fejlődése lehetôvé tette a kereskedelmi funkció szállítói és elosztói hálózatról való hatékony leválasztását. Ráadásul az egyes kormányzatok egyre nagyobb mértékben vonulnak ki az infrastrukturális iparágakból, és jelentős erőfeszítéseket tesznek a villamosenergia-ágazatra vonatkozó szabályozás és a szociális és gazdaságpolitikai kérdések szétválasztására.

A XX. század utolsó évtizedéig az európai villamosenergia-ágazatok a javarészt állami tulajdonban lévố ${ }^{1}$, szabályozott, vertikálisan integrált szolgáltatókból álltak, melyek egy adott régióban, vagy országban monopóliumként tevékenykedtek. A villamosenergiaellátás valamennyi lépésének egyetlen szervezetbe való integrálása viszonylag egyszerú piaci struktúrát jelentett. Ahogyan az 1. ábra is mutatja, a fogyasztók ebben a modellben kvázi külsố szereplóként vannak jelen, nincs beleszólásuk sem a technológiai rendszer fejlódésébe, sem a technológiai rendszer döntéshozatali folyamataiba. Ráadásul a monopol szolgáltatókkal szemben „kiszolgáltatott helyzetben” vannak, hiszen nincs lehetôségük az áram más forrásból való beszerzésére. A villamosenergia-árakat az állam határozza meg,

1. ábra

Piacszerkezet a hagyományos monopol, illetve a teljesen liberalizált modellben

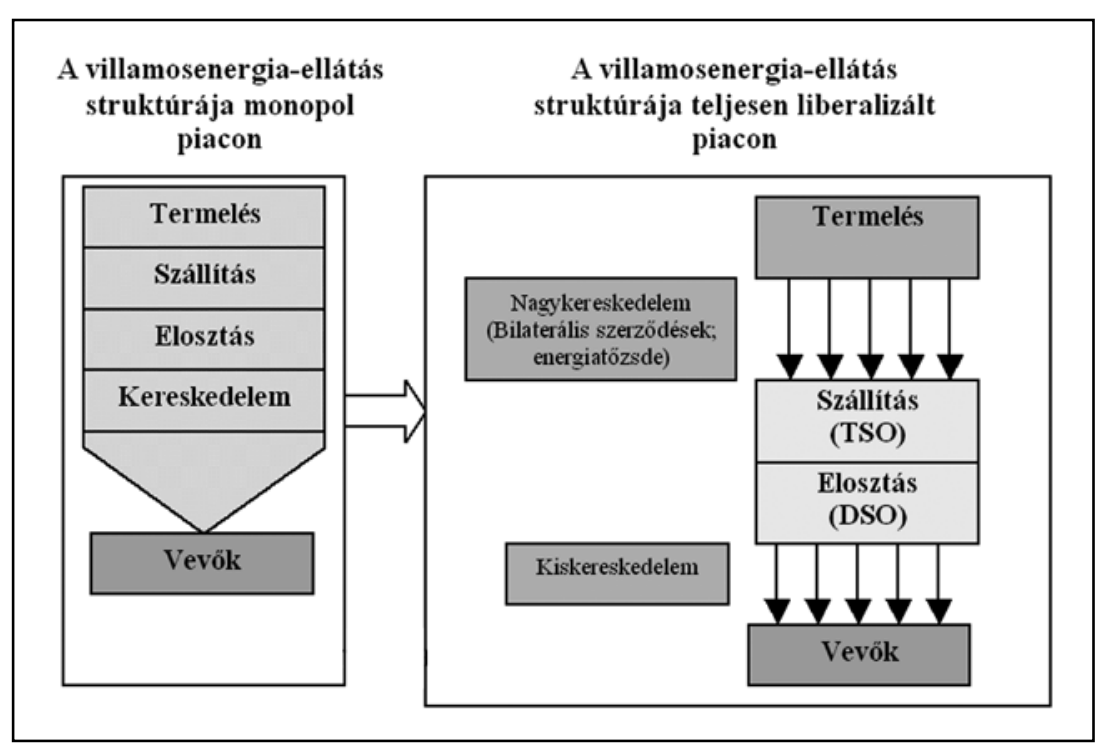

Forrás: saját szerkesztés

VEZETÉSTUDOMÁNY 
a villamosenergia-rendszer összköltsége alapján, oly mértékben, hogy az a költségeken felül profitot is biztosítson a szolgáltatók számára. Ebbôl azt a következtetést is levonhatjuk, hogy a villamosenergia-rendszer stratégiai döntéseit nem a rendszer szereplői, hanem a szabályozó hatóság hozza (1. ábra).

Ezzel szemben az EU által megteremteni kívánt, teljesen liberalizált piaci modellben a szállítási és elosztási piacok közös jellemzője, hogy az egyik oldalon mindig adminisztratív szabályozás alatt álló természetes monopólium áll, azaz a verseny számára két funkció nyitott, a villamosenergia-termelés és a villamosenergia-kereskedés. A villamosenergia-termelés nagykereskedelmi piacán az egyes termelő erőmúvek szabadon értékesíthetik az általuk elóállított energiát és megszúnik a szolgáltatók kiskereskedôi jogának monopóliuma is (2. ábra).

Vállalattípusok az EU villamosenergia-piacain
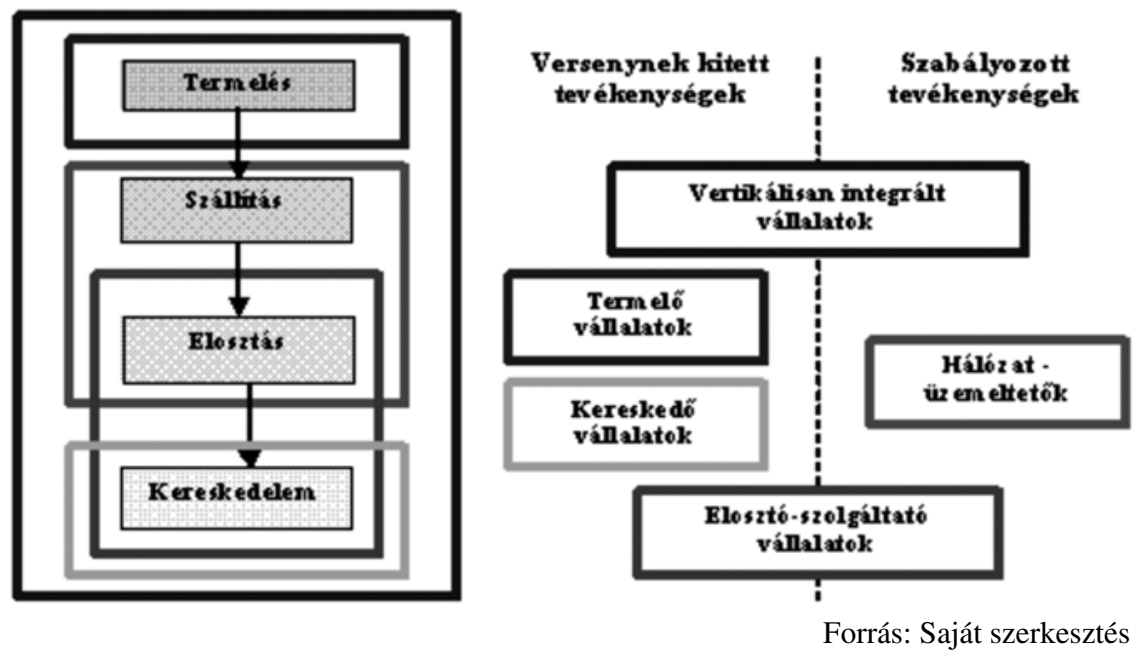

2. ábra

piacokon elosztói hálózattal rendelkező elosztói hálózati irányítók, valamint a villamosenergia-, gázszállítás és elosztás területén érdekelt cégek is. Emellett az EU tagországaiban közel 3000 olyan vállalat tevékenykedik, melyek kizárólag a regionális piacokon folytatnak elosztói és kereskedôi tevékenységet. Új piaci belépóknek számítanak továbbá a vertikálisan integrált vállalatoktól, regionális elosztói-, kereskedő vállalatoktól független, kiskereskedelmi tevékenységet folytató vállalatok. E szereplôi csoportok közül a továbbiakban a vertikálisan integrált, kvázi integrált vállalatok által követett stratégiák vizsgálatára teszek kísérletet.

\section{Vállalati és üzleti stratégiák a villamosenergia-ágazat domináns szereplôinél}

Szabályozott piaci környezetben a villamosenergia-szolgáltatók piacai viszonylag stabilak voltak, az árakat az állam szabályozta, sok esetben az állam volt az egyetlen tulajdonos, így a monopolhelyzetben lévő vállalatoknak nem volt igazán szükségük stratégiai eszközök alkalmazására. A makrokörnyezeti és ágazati változások hatására a kialakulóban lévő központosított, liberalizált villamosenergia-rendszerben egyre nagyobb igény merül fel a vállalati stratégiai és taktikai tervezés iránt.

A hagyományos villamosenergia-rendszerben a vertikálisan integrált vállalatok adott termék-piac kombinációval (homogén terméke-

A piaci szerkezet ezen átalakítása új szereplői csoportokat hívott életre. Továbbra is jelen vannak a vertikálisan integrált vagy kvázi integrált vállalatok, melyek aktívan részt vesznek a villamosenergia-ellátási lánc valamennyi szintjén. Ez a hét vállalat jelenleg a teljes piac mintegy 42\%-át uralja. Beszélhetünk továbbá elsôdlegesen nemzeti piacaikon domináns szerepet betöltô, villamosenergia-termelésre összpontosító vállalatokról is, melyek vagy saját használatra, vagy a nagykereskedelmi piacokon történő értékesítés céljából állítanak elő villamos energiát, vagy megújuló termelési technológiákat alkalmazó új piaci belépóknek tekinthetók. Az új piaci szereplői csoportok egyikét a szabályozott tevékenységet folytató hálózatüzemeltetók képezik. Ide tartoznak a tulajdonosi függetlenséggel bíró, elsősorban nemzeti piacokon jelenlévő szállítói hálózatirányítók, a regionális ket biztosítottak a szolgáltató területen található valamennyi fogyasztó számára) bírtak, beruházási és fejlesztési döntéseik is csak a berendezésekkel, eszközökkel és erőmúvekkel voltak kapcsolatosak. Ezzel szemben a liberalizált piacon tevékenykedő vállalatok stratégiai tervei már kiterjedhetnek a különböző termék-piac kombinációk fejlesztésére, valamint a felvásárlások és egyesülések, az energiamixek változtatásának beruházási kérdéseire is. Míg a monopol piacokon tevékenykedó vállalatok taktikai tervei a termelési, szállítási kapacitás technikai használatával, illetve az esetlegesen előálló hibák megoldására kidolgozott forgatókönyvekkel foglalkoztak, addig a versenypiacokon tevékenykedő vállalatok taktikai megfontolásai az új piacokra való belépés terveit, illetve a megszerzett piaci eró érvényesítését is felölelhetik (Woerd - Lise - Becker, 2004). 
Az elmúlt évtizedben a már piacon lévó, magas piaci részesedéssel bíró vállalatok az ágazatot érintố szabályozási és strukturális változásokra, a növekvó pénzügyi és részvényesi elvárásra, a gáz-és villamosenergia-szektorok konvergenciájának erốsödésére, az újonnan belépók fenyegetettségének emelkedésére, a korábban „foglyul ejtett” vevók alkupozíciójának erósödésére, illetve a globalizációra reagálva, a meglévó pozícióik védelmére, erôsitésére helyezték a hangsúlyt. Ahogyan azt a különböző kutatások (Codognet et al., 2002; Thomas, 2003; Verde, 2008) igazolják, a termelési és elosztási hatékonyság fokozásának korlátai miatt, a szolgáltatók mindennek biztosítását a vállalati növekedési stratégiában látták. Egy erősen tókeintenzív ágazatban, mint amilyen a villamosenergia-szektor is, ahol az éves amortizáció értéke kifejezetten magas, még az alacsonyabb profittal bíró vállalatok is olyan magas cash flow-val bírnak, mely a további beruházások, a további növekedés forrásául szolgálhat. A trendek azt mutatják, hogy az elmúlt évtizedekben a piacon lévó vállalatok a rendelkezésükre álló forrásokat a vertikális integráció fokozására, a szervezeti méret és piaci részesedés növelésére, valamint a kapcsolódó diverzifikáció finanszírozására használták.

A vállalatok vertikális integráltságának megtartásával járó elốnyöket számos empirikus tanulmány (pl. Landon, 1983; Lee, 1995; Kwoka, 2002; Kaserman - Mayo, 1991) tárgyalja. Ezen irodalmak a piaci szereplők vertikális integráció megőrzésére tett lépéseit az ellátási láncon belüli technológiai függóség, az információs és tranzakciós igények és árazási nehézségek miatt fellépó óriási tranzakciós költségekkel, a vertikális integráció biztosította magasabb hozzáadott értékkel, költségmegtakarítással és technológiai hatékonysággal magyarázzák. Emellett felhívják a figyelmet arra, hogy a vertikálisan integrált vállalatok vannak kitéve legkevésbé az áringadozásoknak (amennyiben tartani tudják a megfeleló egyensúlyt a villamosenergia-ellátás egyes szakaszai között ${ }^{2}$, és piaci változások esetén képesek a megfelelő tevékenységet középpontba állítani). Ráadásul a vertikálisan integrált vállalatok üzleti modellje az újonnan piacra lépókkel szemben is védelmet biztosíthat, hiszen annak lemásolása hosszú, tókeigényes feladat.

A szervezeti méret és piaci részesedés növelése egyrészt segítheti a méretgazdaságossági hatás érvényesülését, a vállalatok piaci pozíciójának védelmét és erejének érvényesítését, a fejlesztések finanszírozását, miközben a nagyobb, diverzifikáltabb termelési portfólió csökkentheti az áringadozások hatásait, ellátásbiztonsági szempontból is kedvezó hatással járhat (Chao et al., 2005).
A földrajzi értelemben új piacokra, új üzletágakba való belépés olyan általános növekedési stratégia, melyet főleg a piaci erő, a választékgazdaságosság, a kockázatmegosztás növelésének szándéka ösztönöz (Porter, 1987). Míg a piacnyitást követốn a villamosenergia-ágazat nagyvállalatainak egy része a gáz, a telekommunikáció, a víz és a hulladékkezelési ágazatokba belépve vált multiszolgáltató vállalattá, az elmúlt években megfigyelhetô a kapcsolódó diverzifikáció (az energiaszektor egyes alágazataiban való jelenlét) erôsödése. Ezt pedig a villamosenergia- és a gázszektor közötti, a szabályozás, a termékek és szolgáltatások, valamint a technológiák terén is erősödő konvergencia támogatja (Bergstrom - Callender, 1996; McLaughlin - Mehram, 1995). Míg a nagykereskedelmi piacokon a földgázalapú termelési technológiák terjedése miatt a gáz és az áram értékesítése egymást helyettesítheti, addig a kiskereskedelmi piacokat tekintve a gáz- és villamosenergia-szolgáltatások (mérés, számlázás, vevôszolgálat stb.) hasonlósága miatt a vevő́k hajlandók azokat egy vállalattól igénybe venni. Mindezen tendenciáknak köszönhetốen a hagyományosan gáz-, illetve villamosenergia-vállalatok célkitúzései, stratégiai pozicionálása is közeledik egymáshoz.

A piacon lévô vállalatok növekedési stratégiájuk eszközéül, a szerves növekedés korlátozottsága, elsősorban a beruházások kivitelezésének és megtérülésének nagyon hosszú volta (általában 10-30 év), a hatékonysági növelési programok alacsony költségcsökkentő hatásai, valamint a meglévô piacokon a kereslet növekedésének (Nyugat-Európában évi kb. 2,1\%) lassulása - miatt a külsố, az egyesülések és felvásárlások, együttmúködések ${ }^{3}$ révén történő növekedést választják. A szerves növekedéssel szemben ez lehetôvé teszi számukra a hiányzó képességek, ismeretek megszerzését, miközben szinte azonnal elérhetô kapacitásnövelést, részesedésnövekedést, erôsítést biztosíthat.

A villamosenergia- és gázszektor liberalizációs folyamatainak beindulásával az egyesülések és felvásárlások száma és értéke is jelentôsen megnőtt 1998 és 2009 között. Codognet et al. (2002) felmérései azt mutatják, hogy az általunk vizsgált időszakban (1998-2002), a határokon belüli egyesülések és felvásárlások részaránya volt a meghatározó. A PwC (2009) felmérése szerint bár a hazai piacokon zajló egyesülések és felvásárlások aránya 2002-tôl is jelentôs maradt, a határokon átnyúló tranzakciók száma és értéke 2005, 2006, 2007ben is duplája volt a korábbi évek eredményének, ami a gáz- és villamosenergia-szektorok nemzetköziesedését igazolja. Amennyiben az ágazaton belüli és ágazatok közötti egyesülési és felvásárlási tranzakciókat vizsgáljuk, megállapítható, hogy az ágazatokon átnyúló egye- 
sülések és felvásárlások aránya 2000 óta növekszik (Verde, 2008). Verde (2008) véleménye szerint mindezen adatok kétféle trendet támasztanak alá. Egyrészt mutatkozik egyfajta tendencia a páneurópai, illetve a nemzeti piacokon domináns hazai vállalatok, vállalatcsoportok kialakulása felé. Másrészt a már piacon lévő vállalatok arra törekednek, hogy minél erôsebb pozíciókat építsenek ki az új belépókkel szemben. Amenynyiben ugyanis az európai piacok teljesen liberalizálttá válnak, és az infrastrukturális beruházások lehetôvé teszik a közös európai piac létrehozását, a tevékenységek földrajzi, ágazati kiterjesztése biztosíthatja a domináns piaci jelenlétet, a tanulási hatás érvényesülésének sajátosságait, illetve a más vállalatok általi lehetséges felvásárlás kockázatának csökkenését (Verde, 2008). Természetesen az egyesülések és felvásárlások alkalmazása, a növekedési stratégia követése csak abban az esetben kedvezố a vállalatok számára, ha az képes értéket (a megtérülés magasabb, mint a tóke költsége) teremteni, hiszen ebben az esetben járul hozzá a vállalat pénzügyi helyzetének erősödéséhez.

A villamosenergia-rendszer vállalatainak versenystratégiái is érdekes vizsgálati területet képviselnek. Porter (1980) szerint bármilyen stratégiát is követ egy vállalat, az versenystratégiának számít, hiszen annak elsố számú feladata, hogy tartós versenyelónyt biztosítson számára. Megközelítése szerint a versenyelôny két forrását a költségelőny és a megkülönböztetésból eredő előny képviseli, és a vállalatok, stratégiai üzleti egységek számára a versenyelôny forrásai, valamint a piaci célterület alapján három általános versenystratégiatípus (költségvezető, megkülönböztetô, összpontosító) javasolható.

1. táblázat

\section{Porter-féle versenystratégiák a villamosenergia-ágazatban}

\begin{tabular}{|c|c|c|c|}
\hline & \multicolumn{3}{|c|}{ A versenyelóny forrása } \\
\hline \multirow{2}{*}{$\begin{array}{c}\text { Célpiac } \\
\text { mérete }\end{array}$} & Tág & Költségvezetô & Megkülönböztetô \\
\cline { 2 - 4 } & Szúk & $\begin{array}{c}\text { Fókuszált } \\
\text { költségvezető }\end{array}$ & $\begin{array}{c}\text { Fókuszált } \\
\text { megkülönböztető }\end{array}$ \\
\hline
\end{tabular}

Forrás: Porter (1980)

A villamosenergia-szektorban - mint ahogyan számos, dereguláción átesố közszolgáltatási ágazatban is - a piaci liberalizáció révén a Porter (1980) által megfogalmazott versenystratégiák is előtérbe kerülhetnek (1. táblázat). A villamosenergia-ágazat vonatkozásában elsósorban a költségvezetó és a fókuszált megkülönböztetố versenystratégiák a kiemelendók.

Amennyiben elfogadjuk a villamosenergia-ellátás homogén szolgáltatásként történő kezelését és az egy- ségeken alapuló értékesítés modelljét, akkor megállapítható, hogy a szektor vállalatai számára a költségvezetó versenystratégia követése az elsődleges alternatíva. Ennek oka, hogy míg a monopol piaci körülmények között a vertikálisan integrált vállalatok bevételei a központilag meghatározott, „,foglyul ejtett” vevóknek kiszabott díjakból származtak, a piacnyitással a vállalati bevételek a villamos energia egységeinek, a piac, illetve a verseny által meghatározott árakon való értékesítéséből, tranzakcióiból erednek. A költségalapú versengés kockázatokat is hordoz magában. A verseny intenzitásának erôsödésével, az árak csökkentésével a vállalati profitrés egyre szúkebbé válhat, ha pedig azt is számításba vesszük, hogy a vevớk viszonylag könnyen tudnak szolgáltatót, termelốt váltani, és ennek megfelelően a vevő́i bázis erôteljesen ingadozhat, a villamos energia egységenként történó értékesítési módja csak korlátozott stratégiai lehetôségeket tartogat. Ez ösztönözheti az ún. kapacitáslekötés-alapú fizetési szerződések ${ }^{4}$, illetve a hosszú távú, fix áras szolgáltatások (pl. világítás biztosítása) alkalmazását, előtérbe kerülését (Patterson, 2007).

A megkülönböztetési stratégia folytatásának kritikus eleme, hogy annak a vevői elvárásokra, igényekre kell épülnie. Más szavakkal, a vevók felfogása szerint az ezen stratégia keretében értékesített termékek vagy szolgáltatások eltérnek versenytársaikétól, így azokért akár magasabb árat is hajlandók fizetni. Következésképpen, a vállalatok akkor folytathatnak sikeres megkülönböztetô stratégiákat, ha a stratégiák révén szerzett többletbevételeik meghaladják a termékek vagy szolgáltatások megkülönböztetésének többletköltségeit, miközben az adott vállalat kellố mennyiséget tud értékesíteni belőlük. A villamos energia esetében a megkülönböztetési stratégia a zöld áram kínálatára korlátozódhat. ${ }^{5}$

A villamosenergia-piacok deregulációjával, a környezetvédelmi elôírások szigorodásával, az energiapolitikai célkitúzések megújuló energiahordozók arányának növelésére helyezett hangsúlyával, a fogyasztói környezettudatosság erősödésével ugyanis megnyílik a lehetőség a zöld energiára alapuló megkülönböztetés előtt. Ugyanakkor léteznie kell egy olyan fogyasztói csoportnak, mely hajlandó magasabb egységárat fizetni a környezetbarát villamosenergia-szolgáltatásért, és bár a megkülönböztetés szinte valamely módja értékes lehet vevő́k bizonyos csoportja számára, nem elhanyagolható szempont, hogy a megcélzott vevôi csoportnak elegendôen nagynak kell lennie a stratégia és a vállalat fennmaradásához. Úgy vélem, hogy a magasabb környezettudattal rendelkezó vevók körében, és a termelésben használt energiahordozó-mix megfeleló stratégiai elmozdításával lehet sikeres, rövid távon mindenképp összpontosító megkülönböztetést alkalmazni. 
Másodszor, a vevői fizetési hajlandóság ösztönzése a villamos energia esetében korlátokba ütközik. Míg bizonyos környezetbarát termékek alkalmasak az egyéni többletérték növelésére, az áram esetében a vevók oldalán az otthoni használatnál már semmilyen ,zöld” jelleg, tulajdonság ${ }^{6}$ nem jelentkezik. A szúk vevôi kör ${ }^{7}$ miatt az is megfigyelhetô, hogy a villamos energia jelenlegi rendszerében ez a versenystratégia csak az aktív állami szerepvállalás (pl. beruházástámogatás, ökoadók, kötelezô átvétel, kvóták stb.) révén tartható fenn (Woerd Lise - Becker, 2004), illetve ezek segítségével alakítható át, hosszabb távon, tág piacra érvényes megkülönböztetô stratégiává.

A megkülönböztető versenystratégia választását nemcsak a keresleti tényezók, hanem az adott vállalat, vállalatcsoport jellemzói is befolyásolják. A piacon lévő vállalatok mindaddig számíthatnak a magas amortizációs (adóvédelmi) értékre, míg a meglévő eszközállomány alkalmazásban van. Ez pedig részben azt is jelenti, hogy a dominánsan fosszilis energiahordozókra épülố termelési technológiai bázissal rendelkezố vállalatoknál a meglévô termelési kapacitások megújuló energiahordozókra épülő technológiákkal való „kiváltása” csak nagyon lassan mehet végbe. Bár a rendelkezésükre álló szabad cash flow biztosítaná a kockázatosabb tevékenységek, technológiák termelési portfólióba történố bevételét, a vállalatok többsége csak korlátozott mértékben él ezzel a lehetôséggel. Elsősorban a $\mathrm{K}+\mathrm{F}$ tevékenységek kockázatossága és a verseny intenzitásának erősödése miatt.

Véleményem szerint a piacon lévó vállalatok közül azoknál kerülhet inkább alkalmazásra, melyek eróforrásait, képességeit csak minimális mértékben érinti a stratégiaváltás ${ }^{8}$, melyek reputációja nem kötódik szorosan a fosszilis energiahordozók hasznositásához, hiszen ebben az esetben hiányozhat a vevói legitimáció, illetve azok a vállalatok, melyek alacsony termelési hatékonysággal bírnak, ebben az esetben ugyanis csak korlátozottan képesek az erốs árversenyben részt venni.

A megújuló energiahordozókra épülő fókuszált megkülönböztetési stratégia folytatása így inkább az újonnan piacra lépő termelő vállalatokra jellemző, amelyek könynyebben vezethetik be ezt az új üzleti modellt, mint a már kialakult rendszerrel, évtizedes tapasztalatokkal ren-

delkezố társaik. Így véleményem szerint nagyobb a valószínúsége annak, hogy a nagy, vertikálisan integrált vállalatok többsége kivárja a megújuló technológiák, illetve az azt alkalmazó, többségében újonnan belépő vállalatok sikeres felfuttatását, majd ezt követően állítja azokat felvásárlási és egyesülési törekvései célpontjába.

\section{Az Európai Unió villamosenergia-piacain domináns részesedéssel bíró vállalatok stratégiai csoportjai}

A gáz- és villamosenergia-ágazatok konvergenciájával, a villamosenergia-ágazat konszolidációjával, valamint a megújuló energiahordozók alkalmazásával kapcsolatosan tett megállapításaim igazolására a stratégiai csoportok módszerét alkalmazom. Stratégiai csoportok alatt vállalatok azon csoportját értjük, melyek egy adott ágazatban, adott stratégiai dimenziók mentén azonos stratégiákat folytatnak, azonos alapokon versenyeznek (Garinaldi, 2008). Ilyen stratégiai jellemző lehet például a vertikális integráció mértéke, a termékválaszték szélessége, a földrajzi jelenlét, a kínált minôség, a technológiai pozíció, a kiszolgált piacok jellemzói, az alkalmazott disztribúciós csatornák típusa stb. A megfelelóen kiválasztott ismérvek alapján azonosított csoportok világossá teszik, kik a közvetlen versenytársak, milyen irányú elmozdulásokra számíthatunk, hol várható az új belépók fenyegetése (Ilosvai, 2008). A stratégiai csoportosítást az EU villamosenergia-pia- 
cain domináns pozícióval bíró 16 vállalatra készítettem el, a cégek 2001-re és 2008-ra vonatkozó éves beszámolói ${ }^{9}$ alapján. A vizsgált vállalatokat a villamosenergia-ellátási láncban való jelenlétük (vertikális integráltság foka), diverzifikáltságuk (villamos energia, gáz, víz, telekommunikáció stb. piacokon való jelenlét), valamint a megújuló energiahordozókra épüló technológiák kapacitásbővítésben betöltött részaránya alapján soroltam stratégiai csoportokba.

A 3. ábra a vállalatok villamosenergia-ágazaton belüli vertikális integráltsága ${ }^{10}$ és ágazati diverzifikáltsá$\mathrm{ga}^{11}$ alapján képzett stratégiai csoportjait szemlélteti.

Ahogyan azt a 2008-as adatok igazolják, a vizsgált vállalatok e két dimenzió mentén 6 stratégiai csoportba sorolhatók. Az elsố csoportba a vertikálisan integrált, erôsen diverzifikált vállalatok (6., 13., 9. és 2.) kerültek. Köztük olyan vállalatok is szerepelnek, melyek domináns gázpiaci szereplő́kbő́l a szerves és külső növekedést kombinálva jelentek meg a villamosenergiaszektorban. A második csoportot a vertikálisan integrált, közepes mértékben diverzifikált vállalatok (3., 5., 8., 11. és 15.) alkotják. Külön csoportba sorolódtak a vertikálisan integrált, egyszektoros vállalatok (1., 12.), melyek fóként hazai villamosenergia-piacaikon tevékenykednek. A vizsgált vállalatok közül három vállalat
(4., 14. és 16.) esetében figyelhetô meg a villamosenergia-termelési funkcióra történő specializálódás, és egy esetében (10.) beszélhetünk diverzifikált, a villamosenergia-ágazatot tekintve alapvetóen termelési területen versengố vállalatról. A több ágazatban is jelenlévő, a villamosenergia-ellátásban alapvetôen szolgáltatói tevékenységre összpontosító stratégiai csoportot a vizsgált vállalatok közül a 7. számú cég reprezentálja.

A 3. ábra a vállalatok 2001-ben betöltött pozícióit is mutatja, így lehetôvé válik az egyes vállalatok vizsgált idôszak alatti elmozdulásának tanulmányozása. Ahogy azt a 3. ábra is alátámasztja, az elsô öt stratégiai csoportba tartozó szereplő az elmúlt évek kihívásaira a vertikális integráció fokozásával reagált, azaz növelte a termelési és a kiskereskedelmi tevékenységek integrációját, melyet a korábban erôsen diverzifikált vállalatok egy része más ágazatban való jelenlétének „kárára” valósított meg. Ugyanakkor a korábban kevésbé diverzifikált múködési körrel bíró vállalatok egy részénél (pl. 1., 3., 8. és 11.) ennek ellenkezóje figyelhetô meg. Érdemes megjegyezni továbbá, hogy bár az 1., 7., 12. és 15. számú vállalatok is növelték termelési kapacitásukat, jelentôs lépéseket inkább a kiskereskedelmi piacokon való jelenlétük erősítésének irányába tettek.

4. ábra

Stratégiai csoportok a vállalatok vertikális integráltsága és a RES-alapú termelési technológiák kapacitásnövekedési részaránya ${ }^{12}$ alapján

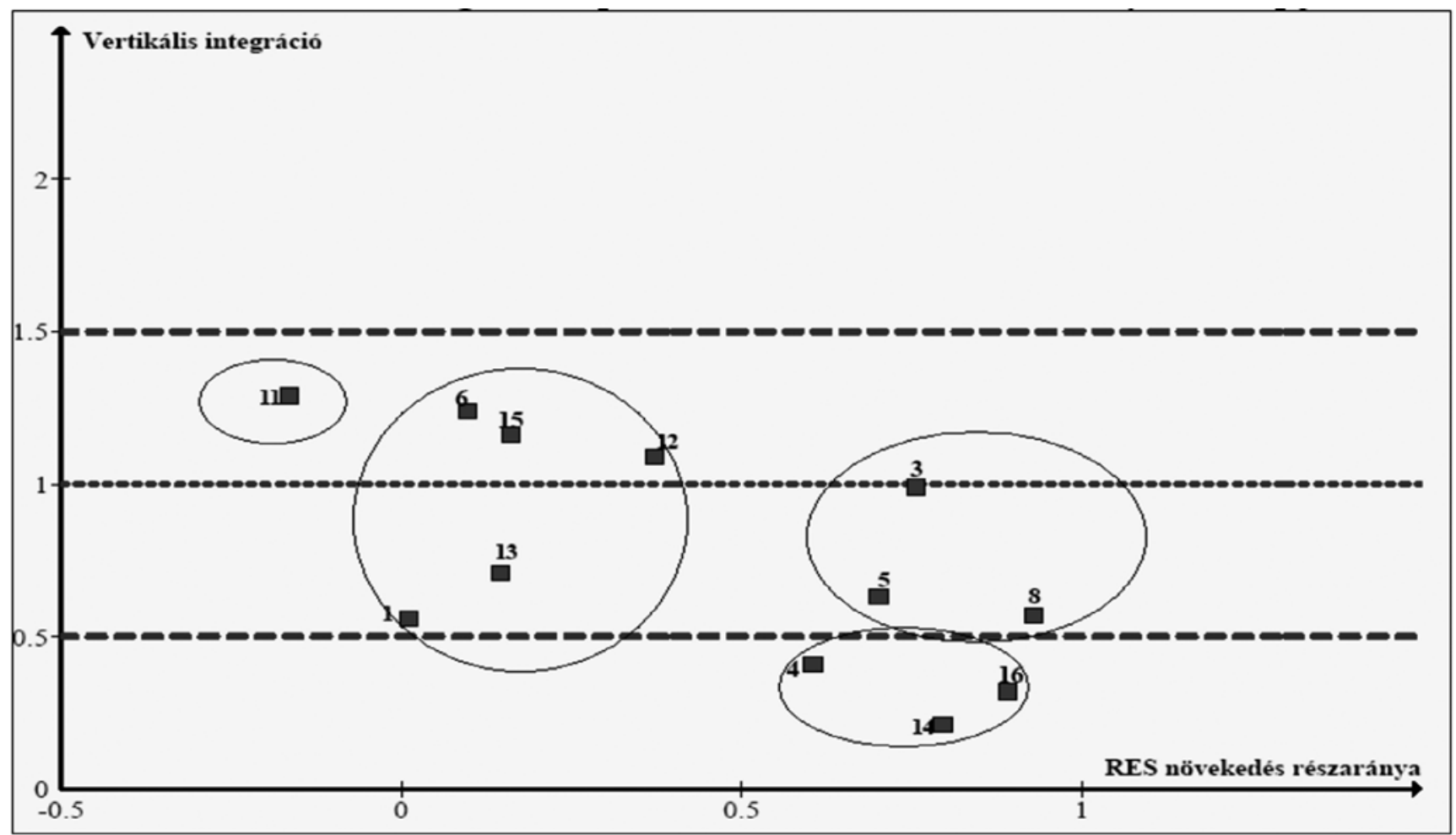

Forrás: Saját számítás a vállalatok éves beszámolóinak 2001-re és 2008-ra vonatkozó adatai alapján 
A 4. ábra a vertikális integráció és a megújuló energiahordozókra épülő termelési technológiák 2001 (illetve 2004) és 2008 közötti kapacitásbővítésben betöltött részaránya alapján helyezi el a vizsgálatban szereplő vállalatokat. Ahogyan a 4. ábráról is leolvasható, ebben az esetben négy stratégiai csoportról beszélhetünk. Az elsố csoportot egy olyan vertikálisan integrált vállalat alkotja (11.), melynél a vizsgált időszak alatt csökkent a megújuló energiahordozóra épülő technológiák termelési kapacitásban betöltött részaránya. A vizsgálatban szereplố vertikálisan integrált vállalatok a megújuló termelési kapacitások növelése szempontjából két fó stratégiai csoportba kerültek. Külön kategóriát képeznek a mérsékelt erófeszítést (1-36\%-os növekedés) felmutató (1., 6., 12., 13., 15.), valamint a kapacitásbóvítés során a fosszilis termelési egységeket háttérbe helyező (3., 5., 8.) cégek. A vizsgálatban szereplő, elsődlegesen termelési funkcióra specializálódott (4., 14., 16.) vállalatok esetében megállapítható a RES-technológiák irányába történô erôteljes elmozdulás.

Érdemes megemlíteni, hogy a termelési területre specializálódott vállalatoknál a megújuló energiatechnológiák termelési kapacitáshoz mért részaránya 2001ben, illetve 2004-ben is meghatározó mértékú volt. Annak ellenére, hogy a vizsgált időszak alatt, jelentős erőfeszítéseket téve, néhány vertikálisan integrált vállalat (pl. 4., illetve 13.) megduplázta, megtriplázta a megújuló energiahordozóra épülő erômúvi kapacitását, elsôsorban a felvásárlások útján történô külsố növekedési stratégia miatt a kapacitásbővülést jelentős mértékben a fosszilis, illetve nukleáris erőmúvi kapacitások terén bekövetkezett növekedés támogatta. Mindez pedig alátámaszthatja a megújuló energiahordozókra épüló technológiák használatára és a zöld áram értékesítésére épülő stratégiára vonatkozó megállapításaimat.

\section{Összegzés}

Az Európai Unió energiapiacait érintő intézményi változások átrajzolják az iparági határokat, kitágítják a piacon lévő és az újonnan belépni szándékozó vállalatok mozgásterét, miközben a vállalatok magatartását is megváltoztatják. Míg a szabályozott piaci környezetben a szektor vállalatainak stratégiái fóleg a hálózatfejlesztés, kapacitásbővítés kérdéseire szorítkoztak, addig a liberalizáció révén elóálló versenypiac megköveteli, hogy a vállalatok képesek és készek legyenek a makroés mikrokörnyezetben, a versenytársak stratégiáiban, a vevốk elvárásaiban bekövetkezố változásokra reagálni. Ahogyan láthattuk, a már piacon lévő vállalatok arra törekednek, hogy erós pozíciókat építsenek ki mind a hazai, mind a nemzetközi piacokon azért, hogy megốriz- zék és fejlesszék a termelési és a kiskereskedelmi tevékenységek integrációját, mely az intenzív egyesülések és felvásárlások legfóbb indokának tekinthetó. Amenynyiben a konszolidációs trendek folytatódnak, az Európai Unió piacait néhány, vertikálisan integrált vállalat uralja majd, melynek köszönhetően előfordulhat, hogy a korábbi monopol piaci szerkezet oligopol szerkezetté változik, ami jelentôs korlátot képezhet az újonnan belépni szándékozókkal szemben. A környezetvédelmi szabályozások szigorodására reagálva mind a hét - az európai piacokon domináns piaci részesedéssel bíró, - vertikálisan integrált nagyvállalat tovább erósítette pozícióját az atomenergia-hasznosítás terén is, jócskán meghaladva a megújuló technológiák, illetve energiahatékonysági fejlesztések terén elért eredményeiket. Bár ezek a vállalatok megpróbálnak eleget tenni a szabályozási elvárásoknak, új piaci kihívásoknak és az újonnan megjelenô, terjedó fogyasztói elvárásoknak, számos kutatási projektet kezdeményeznek a megújuló energiahordozókra épülő termelési technológiák és hálózati megoldások vonatkozásában, jövőjüket alapvetően még mindig a hagyományos üzleti modellre és technológiákra, illetve azok továbbfejlesztésére építve képzelik el.

\section{Lábjegyzet}

${ }^{1}$ Kivéve Németországot, ahol a beruházói, vevôi, önkormányzati tulajdon egyfajta keveréke jött létre.

2 Általánosan elfogadott nézet, hogy kedvező helyzetben vannak azok a vállalatok, amelyek képesek az árbevétel legalább 40\%-át saját termelésból fedezni.

${ }^{3}$ Számos vertikálisan integrált vállalat kötött együttmúködési szerződést a regionális piacokon tevékenykedő elosztó-szolgáltatóvállalatokkal.

${ }^{4}$ A kapacitásalapú lekötésnél nem a felhasznált árammennyiség után kell fizetni, hanem a teljes rendszer igénybevételére kiszabott díjat kell megtéríteni.

${ }^{5}$ A villamos energia homogenitása miatt nem lehet más jellemzókre alapozott megkülönböztetést kiépíteni. A társadalmi alapú (pl. foglalkoztatási jellemzók, CSR) megkülönböztetéssel kapcsolatos ismeretek, lehetôségek korlátozottak, illetve megtérülésük jelenleg bizonytalannak túnik.

${ }^{6}$ Azaz, a felhasználókhoz eljuttatott megújuló vagy fosszilis energiahordozóból származó villamos energia jellemzói között nincs észlelhetố különbség.

${ }^{7}$ Ennek ellenére számos gyakorlati példa létezik a ,zöld áram” alapú fókuszált megkülönböztetési stratégia alkalmazására, például a holland PNEM és EDON, a brit Eastern Electricity energiaszolgáltató vállalatok is bevezették a zöld árazási stratégiát.

${ }^{8}$ Azaz a technológiai és energiahordozó-specifikáció miatt a vállalatok nem cserélhetik le az energiahordozókat a termelési technológiák cseréje nélkül. Ezt tovább nehezítheti az új technológiák, energiahordozók alkalmazásával kapcsolatos kompetenciák, szakértelem meglétének hiánya.

${ }^{9}$ A vizsgálatba vont vállalatok: CEZ, Dong, EDF, EDP, ENEL, E.ON, EVN, Fortum, GasNatural-Unión Fenosa, GDF-Suez, Iberdrola, PPC, RWE, Stratkraft, Vattenfall, Verbund. Az Iberdola 
és a Statkraft esetében a 2001-es adatok helyett a 2004-es, míg a GasNatural-Unión Fenosa és a GDF-Suez esetében csak a 2008as adatokat vettem figyelembe. A Dong 2001-es adatai a vállalat gázszektoron belüli integrációjára vonatkoznak.

${ }^{10}$ A vállalaton belüli vertikális integráció mérésénél a termelési és értékesítési tevékenységek egymáshoz viszonyított arányát vizsgáljuk, figyelembe véve a termelt és a végfogyasztók számára értékesített villamosenergia-mennyiségeket. Teljesen integrált a vállalat, amennyiben a két tényezó hányadosa 1 , míg a $0,5 \leq \mathrm{y}<1,5$ intervallumba esố vállalatok saját termelése meghatározó a kiskereskedelmi tevékenységekhez. Ugyanakkor az y $<0,5$ esetén a vállalatok inkább termelés-, míg y>1,5 esetén inkább szolgáltatásorientáltak, így kiszolgáltatottabbak a nagykereskedelmi piacoknak.

${ }^{11}$ A horizontális integráció meghatározása a vállalatok egyes üzletágainak a teljes árbevételhez való hozzájárulása alapján történt, alapul véve a vállalatok esetében alkalmazható, a teljes diverzifikációmérésre kialakított Herfindhal Indexet ( $\boldsymbol{D}=1-\sum_{i=1, N} p_{i}^{2}$ ). Ebben az esetben a TD $\leq 0,2$ esetén a vállalat egy üzletágra koncentrál (Ancar - Sanakaran, 1999).

${ }^{12}$ A RES-alapú termelési technológiák kapacitásnövelési részaránya alatt azt vizsgálom, hogy az adott időszakban az egyes vállalatoknál bekövetkezett kapacitásbeli változás hány százalékát tette ki a megújuló energiahordozók használatára épüló termelési kapacitások növekedése.

\section{Felhasznált irodalom}

Ancar, W. - Sankaran, K. (1999): The myth of the unique decomposability: Specializing the Herfindahl and Entropy measures? Strategic Management Journal, Vol. 20, p. 969-975.

Bergstrom, S.W. - Callender, T. (1996): Gas and power industries linking as regulation fades. Oil and Gas Journal 94, p. 56-65. in: Verde, S. (2008): Everybody merges with somebody - The wave of M\&As in the energy industry and the EU merger policy. Energy Policy, Vol. 36, p. 1125-1133.

Chao, H. - Oren, S. - Wilson, R. (2005): Restructured Electricity Markets: Reevaluation of Vertical Integration and Unbundling. in: Sioshansi, F. P. (eds): Competitive Electricity Markets: Design, Implementation, Performance. Elsevier Global Energy Policy and Economics Series, Elsevier Ltd., London

Codognet, $M-K$ et al. (2002): Mergers and Acquisitions in the European Electricity Sector. Cases and Patterns. CERNA
Finon, D. - Midttun, A. (2004): Reshaping European Gas and Electricity Industries. Elsevier Global Energy Policy and Economics Series, Elsevier Ltd., London

Fraquelli, G. - Piacenza, M. - Vannoni, D. (2005): Cost savings from generation and distribution with an application to Italian electric utilities. Journal of Regulatory Economics, Vol. 28, No. 3, p. 289-305.

Garinaldi, G. (2008): Analyse Stratégique, Éditions d'organisation. Groupe Eyrolles, Paris

Ilosvai P. (2008): Stratégiaalkotás és alkalmazás. PTE, Pécs

Kaserman, D.L. - Mayo, J.W. (1991): The measurement of vertical economies and the efficient structure of the electric utility business. Journal of Industrial Economics, Vol. 39, No. 5, p. 483-503.

Kwoka, J.E. (2002): Vertical economies in electric power, evidence on integration and its alternatives. International Journal of Industrial Organization, Vol. 20, No. 5, p. 653-671.

Lee, B. (1995): Separability test for the electricity supply industry. Journal of Applied Econometrics Vol. 10, p. 49-60.

McLaughlin, R. - Mehram, H. (1995): Regulation and the market for corporate control: hostile tender offers for electric and gas utilities. The Journal of Regulatory Economics, Vol 8, p. 181-204.

Patterson, W. (2005): Keeping the lights on. Earthscan, London

Philipson, L. - Willis, H. L. (2006): Understanding Electric Utilities and De-Regulation. Taylor \& Francis Group, London

Porter, M. (1980): Competitive strategy. The Free Press., New York

Porter, M. (1987): From competitive advantage to corporate strategy. Harvard Business Review, Vol. 65, p. 43-59.

$P w C$ (2009): Power Deals, 2008 Annual Review. htpp:// www.pwc.com, Letöltés ideje: 2010.01.03.

Sioshansi, F.P. (2008): Competitive Electricity Markets: Design, Implementation, Performance. Elsevier Global Energy Policy and Economics Series, Elsevier Ltd., London

Thomas, S. (2003): The Seven Brothers. Energy Policy, Vol. 31, No. 5, p. 393-403.

Van der Woerd, F. - Lise, W. - Becker, G. (2004): Emergent strategies of electricity poroducers. IVM, Report number $\mathrm{R}-04 / 04$.

Verde, S. (2008): Everybody merges with somebody - The wave of M\&As in the energy industry and the EU merger policy. Energy Policy, Vol. 36, p. 1125-1133. 